\title{
Effects of Some Pesticides on Tilapia nilotica and Daphnia magna Life
}

\section{Yasser El-Nahhal ${ }^{1}$,}

\section{Shireen Hams ${ }^{1}$}

Department of Environmental and Earth Sciences, Faculty of Science, Islamic University of Gaza, Gaza Strip, Palestine

* Corresponding author

E-mail address: y_el_nahhal@hotmail.com

https://doi.org/10.33976/IUGNS.28.1/2020/04

\begin{abstract}
:
Application of pesticides creates hazards to the aquatic organisms. This study aimed to determined influence of bromacil, thiabendazole, malathion and mixtures of it on Tilapia nilotica (fish) and D magna. Effects included determination of mortality rate, losing sensation and behavior change (jump attempts) of fish and mortality rate for D. magna using concentration range from 0-6 mg/l. Normal growth of fish and D. Magana was observed under suitable laboratory conditions. The most toxic compound to D. magna was malathion, has an $\mathrm{EC}_{50}$ (Effective concentration that affect $50 \%$ of experimental animal) value of $0.43(\mathrm{mg} / \mathrm{l})$ compared to that of bromacil $0.59(\mathrm{mg} / \mathrm{l})$. Mixture of bromacil and malathion was less toxic than separately and have larger $\mathrm{EC}_{50}$ value 0.64 in toxic unit (TU) indicating potential antagonistic effect. Moreover, thiabendazole was more effective to fish than malathion. Relative toxicity (RT) indicates that thiabendazole has a lower value (0.276) than malathion indicating higher toxicity of thiabendazole. Furthermore, fish and $D$. magna were sensitive to low concentrations. These data indicate potent threats to aquatic organisms.
\end{abstract}

Keywords: Toxicity, fish and D. magna, $\mathrm{EC}_{50}$, Malathion, thiabendazole bromacil 


\section{Introduction:}

Bromacil, malathion and thiabendazol are agrochemicals (herbicide, insecticide and fungicide) widely used in open field and greenhouses for pest control. For instance, large quantities of malathion are being applied in Gaza for controlling Mediterranean fruit fly (seratatus capitata) beside their application in greenhouses and domestic gardens [1] for aphid control. So far, application of bromacil, malathion and thiabendazol may contaminate soil and water systems [2-4], fruits and vegetables [5-6], harmful effects to chicken [7], and have toxic effect among population [8-10]. Several studies determined harmful effects of organic pollutants on aquatic organisms such as unicellular algae, mosquitoes, D. magna and fish [11-14]. Furthermore, other authors investigated the potential individual toxicity test of bromacil and malathion on different organisms [15-17].

Lal, et al. [18] found that malathion treatment may disrupt the endocrine functions, sensation, food intake and retard fish growth. Fish farming industry in Gaza strip progressively increased in the last 10 years and still facing problems such as mortality at early stages. Moreover, fishermen association in Gaza strip documented many dead cases of fish at different size and age (El-Nahhal 2016, personal communication). It was found that aerial application of pesticides resulted in mortality of bees and sea fish. Limited studies investigated influence of marginal concentrations of pesticides or their mixture on aquatic organisms such as fish and D magna. The authors designed this study to answer the following questions: what are the magnitude of toxicity on fish and D. magna using low concentrations; what are the toxicity of pesticide mixtures on the tested animal and what are the response of the tested animal to low concentrations of tested pesticides.

\section{Materials and Methods}

Bromacil (purity 99.7\%), thiabendazole (purity 99.2\%), were purchased from Germany whereas malathion, was supplied by Ministry of Agriculture in Gaza, Palestine, their physical properties are shown in Table 1, and chemical structure is presented in Figure 1. A stock solution of bromacil, thiabendazole or malathion was separately prepared by dissolving a technical amount in $1000 \mathrm{ml}$ distilled water. Toxicity tests was in the range of $0-6 \mathrm{mg} / \mathrm{l}$.

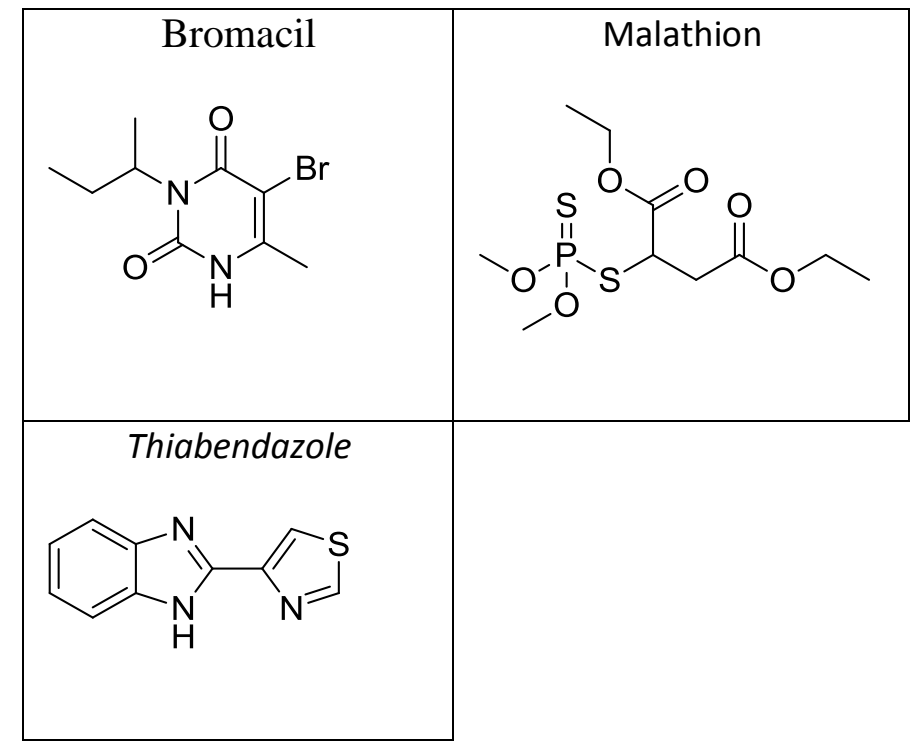

Figure 1 Chemical structure of the tested compounds.

Table 1: Physicochemical properties of the tested compounds.

\begin{tabular}{|l|l|l|l|l|}
\hline Name & $\begin{array}{l}\text { Solubility } \\
\text { in water } \\
\text { mg'l }\end{array}$ & $\mathrm{K}_{\text {ow }} \log \mathrm{P}$ & $\begin{array}{l}\text { Henry } \\
\text { constant }\end{array}$ & $\mathrm{pKa}$ \\
\hline Bromacil & $807-1283$ & 1.88 & - & 9.27 \\
\hline Thiabendazole & $30-160$ & 2.39 & $\begin{array}{l}2.78^{*} 10^{\wedge}- \\
8\end{array}$ & 4.79 \\
\hline Malathion & 145 & 2.75 & - & - \\
\hline \multicolumn{5}{|l}{ Data adopted from Ref [24]. }
\end{tabular}

\subsection{Experimental organisms}

Daphnia magna and fish

Daphnia magna and Tilapia nilotica are aquatic organism widely used as experimental models.

\subsubsection{Breading and acclimatization of Daphnia magna and Fish}


Native population of D. magna obtained from a storm water collection pond in an agricultural area. D. magna population transformed to a $16 \mathrm{~L}$ glass jar. They naturally fed small green algae grown. Two weeks under 12/12 $\mathrm{h}$ dark/light cycle, temperature range $22 \pm 1^{\circ} \mathrm{C}, \mathrm{pH} 7.5 \pm 0.5$, [19] the movement of $\mathrm{D}$. magna indicated their acclimatization, then toxicity tests were conducted as described below.

Fish larvae's, Tilapia nilotica, $(20 \pm 1 \mathrm{~g}$ mean weight, and mean length of $4 \pm 0.5 \mathrm{~cm})$ were supplied by ministry of agriculture, and held in a $50 \mathrm{~L}$ glass container with aeration pump to supply oxygen to the water. Temperature: $25 \pm 1{ }^{\circ} \mathrm{C}, \mathrm{pH}: 7.5 \pm 0.5,12 / 12 \mathrm{~h}$ light/dark photoperiod maintained. Activity of larvae after 2 weeks under the laboratory conditions indicate acclimatization.

Five fish larvae transferred to a glass aquaria $1 \mathrm{~L}$ capacity

\subsection{Toxicity test on fish and Daphnia magna}

Five fish larvae transferred to a deionized water without food in $2 \mathrm{~L}$ glass container containing the required tested concentration dissolve in one liter. Static acute toxicity test was performed to determine the behavior of fish exposed to thiabendazole and malathion during a period of 4 days.

D. magna population was exposed to malathion, bromacil and combination for $48 \mathrm{~h}$ under the same lab conditions, toxicity test was performed in 20 ml glass tubes

Each toxicity experiment contains five concentrations and three replications of each compound.

\subsubsection{Measurement of losing sensation on fish and D. magna}

Losing sensation in fish measured by counting the number of moving fish in the aquarium when the aquarium exposed to an external slightly knock by a wood rod $(20 \mathrm{~cm}$ long and $3 \mathrm{~cm}$ width). This action repeated 5 times for each treatment. D. magan, each tube in the experiment knocked by the same way. The number of moving D. magna in each tube recorded at each knock. This action repeated five times. An average and standard deviation recorded in both fish and D. magana treatments.

\subsubsection{Measuring jumps attempts of fish}

Immediately after adding of the required pesticides concentration in each aquarium, fish tried to jump up from the water. The number of jumping fish from each aquarium recorded and used to calculate percentage fish jump according to equation 1 .

\subsection{Toxicity tests}

According to [20], percentage of fish or D. magna mortality was determined according to equation 1 : $\%$ mortality $=100 *\left(L_{c}-L_{t}\right) / L c \quad E q(1)$

Where $L_{c}$ and $L_{t}$ are average number of live animals in the control and treatment respectively. Regressing \% mortality vs tested concentration enables calculation of lethal concentration required to kill $50 \%$ of the tested animals $\left(\mathrm{LC}_{50}\right)$

\subsubsection{Determination of enzyme activity}

About $2 \mathrm{ml}$ of circulating blood collected from fish for each pesticide concentration used and transferred to special blood container, and then blood samples centrifuged at $10,000 \mathrm{~g}$ for $15 \mathrm{~min}$ at five ${ }^{\circ} \mathrm{C}$ to collect the serum for enzyme activity evaluation.

Activity of acetylcholinesterase activity (AChE) measured spectrophotometrically according to Ellman et al. [21]. Percentage of AChE inhibition calculated according to a previous report [22].-The activities of aspartate aminotransferase (AST) , alanine aminotransferase (ALT) were determined according to Reitman and Frankel [23] whereas, alkaline phosphatase (ALP) determined according to Kid and King [24] using commercially supplied kits purchased from DiaSys, Germany.

\subsection{Determination of pesticide residues in fish samples}

Technical materials of malathion were extracted from a commercial formulation according to procedure described previously $[22,23]$ and used for GC standard curve determination.

\subsubsection{Extraction of malathion residues from fish samples}

Following the procedure previously described $[4,25] 10$ gram fish samples were blended and homogenized with a $10 \mathrm{ml}$ solvent mixture (ethyl acetate/isooctane mixture 1:9 v:v), shacked very well for $20 \mathrm{~min}$ and then separated by centrifugation. The supernatant was collected in $25 \mathrm{ml}$ volumetric flask and the pellets were extracted again with the same solvent mixture as mentioned above. The supernatant was collected and added to the same flask. The volume in each volumetric flask was completed to $25 \mathrm{ml}$ by the same solvent mixture. The content of the flask was poured to a glass funnel containing anhydrous $\mathrm{Na}_{2} \mathrm{SO}_{4}$ to ensure removal of water droplets. A Crimp vial was prepared from each replicate for GC determination. 


\subsubsection{Determination of percentage recovery of malathion from urine sample}

$20 \mathrm{~g}$ of fish macules were collected from the control group, mixed together and subdivided into two groups with two replicates each. Group 1 received $0.1 \mathrm{mg}$, Group 2 received $0.5 \mathrm{mg}$. The samples were carefully shaken. Then, the extraction procedure described above was carefully followed to determine percentage recovery.

\subsubsection{GC determination}

Following the procedure used by Yasser et al., in 2015 [26], the extract was injected into a gas chromatography equipped with a flame photometric detector GC/FPD and a fused silica capillary column $(30 \mathrm{~m}$ long and $0.32 \mathrm{~mm}$ wide with a $0.25 \mu \mathrm{m}$ film thickness). Temperature in the oven was maintained at $230-260^{\circ} \mathrm{C}$. Nitrogen was used as the carrier gas at a flow rate of $2 \mathrm{~mL} / \mathrm{min}$. The hydrogen and air flow rates were 75 and $100 \mathrm{~mL} / \mathrm{min}$, respectively. To insure validity of the method, some extracted samples were determined two times, the first time the extract was determined directly by GC, in the second time the extract was re-concentrated and determined again and comparing the results of $1^{\text {st }}$ and $2^{\text {nd }}$ time determination. In case of no detection in normal extract and detection in the re-concentration extract. This indicates below detection limit in the first detection. In case of no detection in both extracts, this indicates zero level of malathion.

The blank recovery was about $85 \% \pm 5 \%$.

\subsection{Data analysis}

Toxicity were performed in five concentrations and three replicates each. Mean \pm St dev of percentage death were calculated. Regression analysis was done between percentage

death and concentration. $\mathrm{LC}_{50}$ was calculated from a log scale. Relative toxicity (RT) were obtained by dividing $\mathrm{EC}_{50}$ of the tested compound to that of malathion. Values below one indicate high toxicity whereas values above one indicate less toxicity. T-test was used to determine P-values to evaluate the differences among treatments.

\section{Results}

\subsection{Effects to D. magna}

Influence of bromacil and malathion to D. magna population is presented in Figure 2.

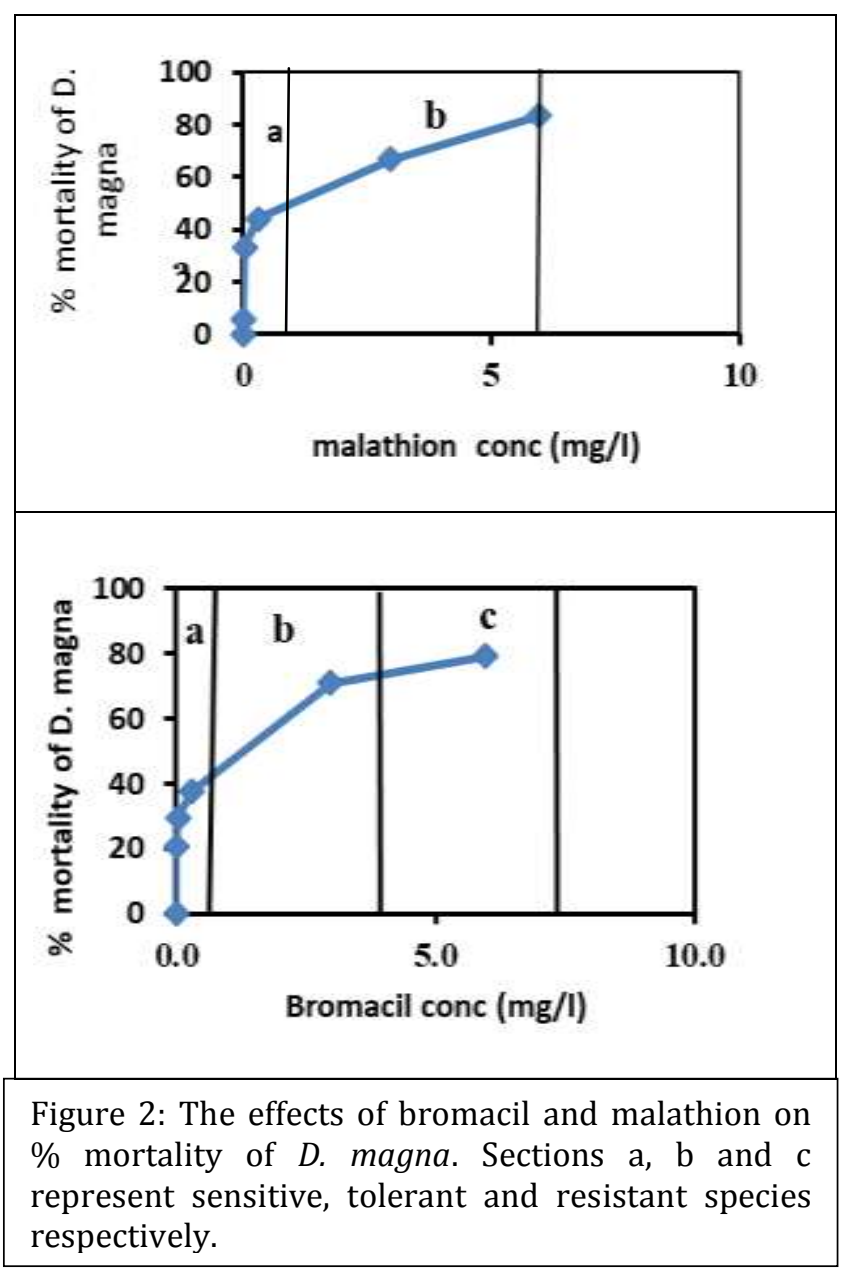


Increases in \% mortality of D. magna was observed as the tested concentration increased. Furthermore, a sharp increase in \% mortality was obtained at a low concentration $(<1 \mathrm{mg} / \mathrm{L})$ of both chemicals. Then, \% mortality increased with different modes.

Toxicity of bromacil and malathion mixture to D. magna is presented in Figure 3. Similarly, to individual toxicity test, mixture of bromacil and malathion produced similar toxicity results with a slight difference.

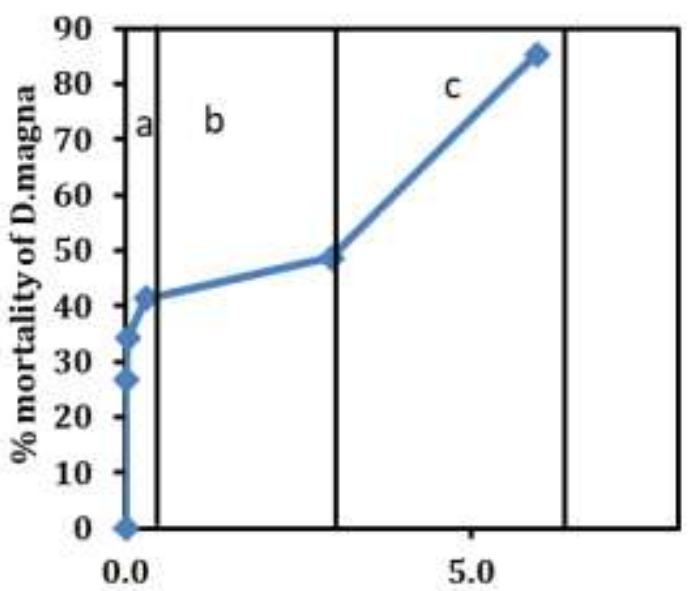

bromacil + malathion $(\mathrm{mg} / \mathrm{l})$

Figure 3: The effects of (bromacil+ malathion) on \% mortality of D. magna. Sections a, b and c represent sensitive, tolerant and resistant species respectively.

\subsection{Toxicity to fish}

Toxicity of malathion and thiabendazole to fish are presented in Figure 4.

It is obvious that losing sensation among tested fish become more sever at high concentrations. These results indicated no mortality at the tested concentrations after 96h. Furthermore, losing sensation thiabendazole test was higher than malathion test.

\subsection{Effects on liver enzymes and AChE.}

Effects of pesticides on liver biomarkers of fish were presented in Table 2. It can be seen that gradual increases of AChE inhibition were observed in the cases of malathion. The maximum inhibition reached to $40 \%$ at malathion concentration $2 \mathrm{mg} / \mathrm{L}$. Furthermore, AChE inhibition also observed on the treatments thiabendazole. Nevertheless, elevated activity of AST, ALP and ALT observed in all cases. These findings are in accordance with findings presented in Figure 4.

Furthermore, percentage recovery of malathion from fish muscles exceeded 83\%, malathion residues in fish samples did not exceed $0.3 \mathrm{mg} / \mathrm{kg}$.

\subsection{Toxicity parameter on D. magna and fish}
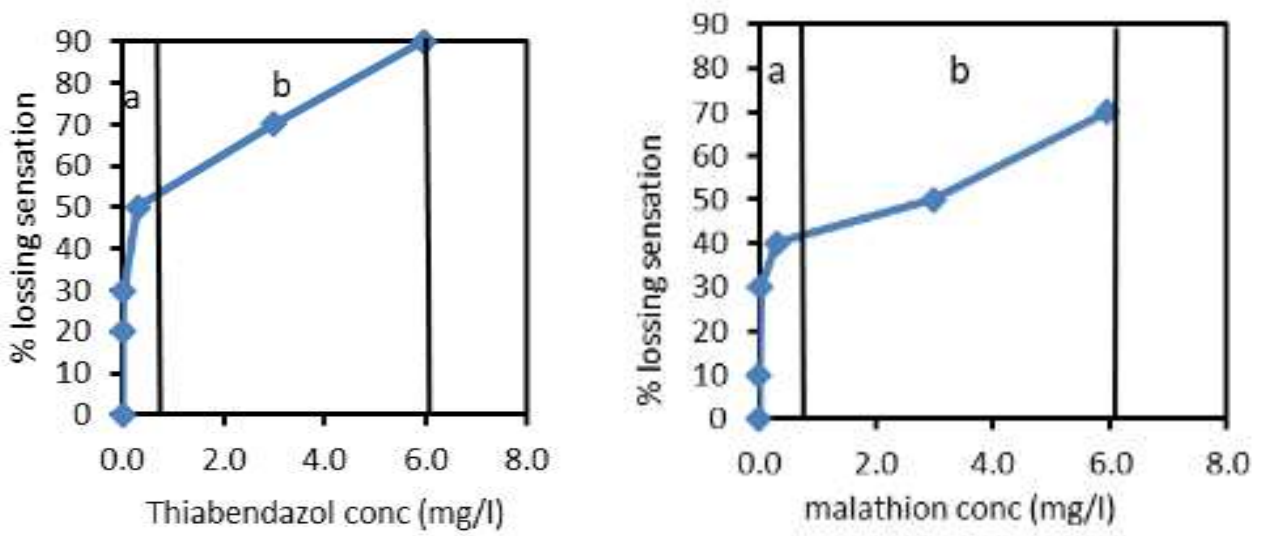
Figure 4. The effects of malathion and thiabendazole on \% losing sensation of fish. Sections a and b represent sensitive, tolerant and resistant species respectively.

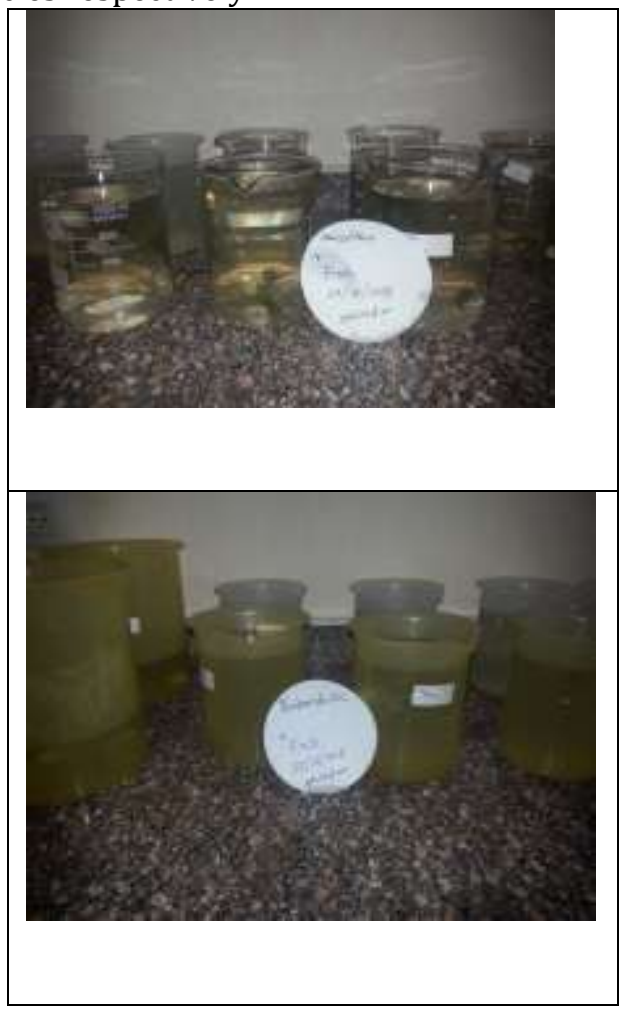

Figure 5: Toxicity of malathion (upper case) and thiabendazole (lower case) to fish.

Toxicity parameters including effective concentration (EC50) required immobilizing 50\% of D. magna or inhibiting fish activity, RT and regression coefficients (Table 3).

It can be noticed that malathion has a low EC50 value compared to other compounds on D. magan test whereas thiabendazole has a low value in fish test. These findings indicate that malathion is the most toxic compound to D. magana whereas thiabendazole is the most toxic one on fish. Furthermore, relative toxicity of malathion RT equals to 1 indicating standard effects, whereas other compounds have higher RT values in D.magna test. On the other hands, RT value for malathion was not the lowest value for fish test. These data suggest that fish is more resistance to malathion than D.magna.

Furthermore, visual rating of toxicity showed no mortality of fish (data not shown).

\section{Discussion}

Bromacil is a herbicide, thiabendazole is a fungicide, and Malathion is an insecticide. These compounds are widely used in agriculture for pest control. So far physical properties such as solubility in water, kow, pKa and Henry constants shown in Table 1, whereas their chemical structure is presented in Figure 1.

\subsection{Toxicity to D.magna}

The findings presented in Figure 2, clearly demonstrates the toxicity of bromacil and malathion to D. magna. It can be noticed that \% mortality has different mode of action. An explanation of these findings is the tested D.magna population contains non-homogenous sensitive species such as follows: type I is a sensitive D.magna specie, type II is a tolerant D.magna specie and type III is a resistant D. magan specie. At low concentration, (less that $1 \mathrm{mg} / \mathrm{L}$ ) all sensitive D.magana species are dead, whereas tolerant and resistant species remained alive. At concentration range 2-6 they dead. So far, this suggestion is clear in bromacil test whereas in malathion test tolerant and resistant species are merged together. Similar observations were previously obtained with mosquito [14, 34]. The difference in malathion can be explained by the fact that malathion is a strong choline esterase inhibitor, which may be metabolized at low concentration to non-/less toxic metabolite in the tolerant and resistant species. Similar observation was previously noticed with D.magan and other pesticides [26]. It is obvious that sections $\mathrm{a}, \mathrm{b}$ and $\mathrm{c}$ are clearly separated from each other with bromacil test whereas in malathion test sections $b$ and $c$ are merged together. Moreover, it can be suggested that section a represents the newly born D.magna during the acclimatization period whereas sections $\mathrm{b}$ and $\mathrm{c}$ represent the parent $\left(1^{\text {st }}\right.$ generation) that were collected from rainwater collected pond and be acclimatized in the lab. 
Furthermore, the data in Figure 3, show toxicity of bromacil and malathion mixture to D. magna. Similarly, to individual toxicity test, mixture of bromacil and malathion produced similar toxicity results. The only difference is that the tolerant species (section b) became more tolerant in the mixture toxicity test than individual test (Figure 2) as shown by reduced mortality from about 70\% in the single test with thiabendazole (Figure 2) to less than 45\% (Figure 3). This suggests an antagonistic effect, which may enhance the development of resistant species.

\subsection{Toxicity to fish}

The data in Figure 4 clearly shows losing sensation of fish without mortality due to exposure to malathion and thiabendazole. The explanation of these results can be due to possible physiological or biochemical properties in fish that enabling fish to survive in aquatic environment containing considerable concentrations of malathion. Furthermore, it can be suggested that malathion may have undergone hydrolysis under aquatic condition, accordingly loss of activity may be obtained. Our suggestion agrees with previous reports [16, 22, 23] which revealed similar observations.

Percentage of losing sensation in thiabendazole test reached about 90\%, which is higher than malathion. This result can be explained by the fact that thiabendazole has different solubility in water, according to $\mathrm{pH}$ whereas malathion has only one solubility in water and less affected by $\mathrm{pH}$ and has higher $\mathrm{K}_{\mathrm{ow}}$ Log $\mathrm{P}$ (Table 1 ). Accordingly thiabendazole fraction that be absorbed by fish gill and make exchange with fish blood is higher than that of malathion, consequently more losing sensation may be obtained. Our results agree with previous report [35]. Furthermore, it can be suggested malathion and thiabendazole reacted with the nicotinic receptors in fish resulting in inhibiting the sensory and motor nerves, accordingly fish losing responses to external parameters. Additionally, section a represents the early response of fish to malathion and thiabendazole whereas section $b$ represents response to high concentration. This may due to the fact that at low concentrations of the tested compounds (malathion and thiabendazole), the molecules can be adsorbed of the surface area of fish and react with the sensory nerves on to the skin of fish. This may result in losing sensation as shown in Figure 4. In section $\mathrm{b}$ (high tested concentration), the tested compounds are adsorbed in the surface area of fish and reacted with surface sensory nerves, then part of the adsorbed materials be penetrated in the blood and reacted with Acetylcholine esterase resulting in further losing sensation.

\subsection{Effects on liver enzymes and AChE}

Effects of pesticide concentration on liver biomarkers are presented in Table 2. Gradual increases of AChE inhibition were observed in the cases of malathion. Maximum inhibition reached to $40 \%$ at malathion concentration $2 \mathrm{mg} / \mathrm{L}$. Furthermore, AChE inhibition was also observed on the treatments of bromacil and thiabendazole. Moreover, elevated levels of AST, ALP and ALT were observed in all cases. These findings are in accordance with data in Figure 4.

Furthermore, percentage recovery of malathion from fish muscles exceeded 83\%, malathion residues in fish samples did not exceed $0.3 \mathrm{mg} / \mathrm{kg}$. This is probably because malathion is highly soluble in water (Tomlin 2000) accordingly, it remained in water due to its Kow value. These findings are in accordance with other cases [25, 26]. Additionally, malathion residues in fish supports the status of AChE and liver enzymes.

Table 2. AChE, AST, ALT and ALP activities in blood serum and malathion residues in fish muscles.

Data presented as an average \pm standard deviation, values between prickets represent percentage enzyme activity change. + and - sings indicate elevation and inhibition respectively. Values in the same column have same letter are not significantly different at $\mathrm{p}$-value $=0.05 . \mathrm{ND}=$ not determined.

Table 2. AChE, AST, ALT and ALP activities in blood serum and malathion residues in fish muscles.

\begin{tabular}{|c|c|c|c|c|c|}
\hline \multirow{2}{*}{ Treatment } & \multicolumn{3}{|c|}{ Enzyme Activity in blood serum (u/L) } & $\begin{array}{c}\text { Malathion } \\
\text { residues } \\
\text { Mg/kg }\end{array}$ \\
\cline { 2 - 5 } & AChE & AST & ALT & ALP & 00 \\
\hline & $\begin{array}{c}\text { a } 8966 \pm 85 \\
(-00)\end{array}$ & $\begin{array}{c}{ }^{\mathrm{a}} 25.3 \pm 3.3 \\
(+00)\end{array}$ & $\begin{array}{c}{ }^{\mathrm{a}} 25 \pm 5.2 \\
(+00 \%)\end{array}$ & $\begin{array}{c}{ }^{\mathrm{a}} 46.1 \pm 1.1 \\
(+00 \%)\end{array}$ & \\
\hline Control & ${ }^{\mathrm{a}} 7953 \pm 79$ & $\mathrm{~b}^{\mathrm{b}} 34.0 \pm 5.2$ & $\mathrm{c}^{\mathrm{b}} 36.7 \pm 3.2$ & ${ }^{\mathrm{b}} 48.2 \pm 2.8$ & $\mathrm{bd}$ \\
Malathion 0.1 & $(-11 \%)$ & $(+34 \%)$ & $(+47 \%)$ & $(+5 \%)$ & \\
\hline Malathion & ${ }^{\mathrm{b}} 7565 \pm 96$ & $\mathrm{~b}^{\mathrm{b}} 35.3 \pm 4.2$ & $\mathrm{~b}^{\mathrm{b}} 37.9 \pm 3.1$ & $\mathrm{~b}^{\mathrm{b}} 47.9 \pm 3.2$ & $0.2 \pm$ \\
1 ppm & $(-16 \%)$ & $(+40 \%)$ & $(+52 \%)$ & $(+4 \%)$ & 0.08 \\
\hline Malathion & ${ }^{\mathrm{c}} 5380 \pm 118$ & ${ }^{\mathrm{c}} 45.1 \pm 5.4$ & ${ }^{\mathrm{b}} 38.1 \pm 3.5$ & ${ }^{\mathrm{c}} 55 \pm 2.2$ & $0.29 \pm$ \\
2 ppm & $(-40 \%)$ & $(+78 \%)$ & $(+52 \%)$ & $(+19 \%)$ & 0.13 \\
\hline Bromacil & $\mathrm{Nd}$ & $\mathrm{Nd}$ & $\mathrm{Nd}$ & $\mathrm{Nd}$ & $\mathrm{Nd}$ \\
\hline Thiabendazol & ${ }^{\mathrm{b}} 6543 \pm 163$ & ${ }^{\mathrm{c}} 49.5 \pm 12.4$ & ${ }^{\mathrm{b}} 41.1 \pm 13.5$ & ${ }^{\mathrm{a}} 47 \pm 7.5$ & $\mathrm{Nd}$ \\
& $(-27 \%)$ & $(+96 \%)$ & $(+64 \%)$ & $(+2 \%)$ & \\
\hline
\end{tabular}


Data presented as an average \pm standard deviation, values between prickets represent percentage enzyme activity change. + and - sings indicate elevation and inhibition respectively. Values in the same column have same letter are not significantly different at $\mathrm{p}$-value $=0.05$. ND= not determined.

4.3 Toxicity parameter on D. magna and fish Toxicity parameters including effective concentration (EC50) required to immobilize $50 \%$ of D. magna or inhibit fish activity, relative toxicity (RT) and regression coefficients (Table 3).

Table 3. Toxicity parameters on D. magna and Fish

\begin{tabular}{|c|c|c|c|c|c|c|c|c|}
\hline \multirow{2}{*}{$\begin{array}{l}\text { Treatme } \\
\text { nt }\end{array}$} & \multicolumn{4}{|c|}{ D.magna } & \multicolumn{4}{|c|}{ Fish } \\
\hline & $\begin{array}{l}\mathrm{EC}_{50} \\
(\mathrm{mg} / \mathrm{l})\end{array}$ & $\mathrm{R}^{2}$ & RT & R.Eq & $\begin{array}{l}\mathrm{EC}_{50} \\
(\mathrm{mg} / \mathrm{l})\end{array}$ & $\mathrm{R}^{2}$ & RT & R.Eq \\
\hline $\begin{array}{l}\text { Bromaci } \\
1\end{array}$ & 0.59 & $\begin{array}{l}0.9 \\
7\end{array}$ & $\begin{array}{l}1.3 \\
7\end{array}$ & $\begin{array}{l}Y=0.1 \\
779 X \\
+1.74\end{array}$ & $\mathrm{Nd}$ & $\mathrm{Nd}$ & nd & $\mathrm{Nd}$ \\
\hline $\begin{array}{l}\text { Thiaben } \\
\text { dazol }\end{array}$ & $\mathrm{Nd}$ & nd & nd & $\mathrm{Nd}$ & 0.363 & 0.99 & $\begin{array}{l}0.2 \\
8\end{array}$ & $\begin{array}{l}=0.192 \\
9 X \\
+1.7838\end{array}$ \\
\hline $\begin{array}{l}\text { Malathio } \\
\mathrm{n}\end{array}$ & 0.43 & $\begin{array}{l}0.9 \\
85\end{array}$ & 1 & $\begin{array}{l}Y=0.1 \\
689 X \\
+1.76\end{array}$ & 1.312 & 0.90 & 1 & $\begin{array}{l}Y=0.222 \\
3 X \\
+1.6727\end{array}$ \\
\hline $\begin{array}{l}\text { Thiaben } \\
\text { dazol+B } \\
\text { romacil }\end{array}$ & $\mathrm{Nd}$ & $\mathrm{Nd}$ & $\mathrm{Nd}$ & $\mathrm{Nd}$ & $\mathrm{Nd}$ & $\mathrm{Nd}$ & $\mathrm{Nd}$ & $\mathrm{Nd}$ \\
\hline $\begin{array}{l}\text { Bromaci } \\
1 \\
\text { Malathio } \\
n\end{array}$ & $* 0.64$ & $\begin{array}{l}0.8 \\
4\end{array}$ & $\begin{array}{l}1.4 \\
9\end{array}$ & $\begin{array}{l}Y=0.1 \\
261 X \\
+1.79\end{array}$ & $\mathrm{Nd}$ & $\mathrm{Nd}$ & $\mathrm{Nd}$ & $\mathrm{Nd}$ \\
\hline
\end{tabular}

It can be noticed that malathion has a low EC50 value compared to other compounds on D.magan test whereas thiabendazole has a low value on fish test. The findings indicate that malathion is the most toxic compound to D.magana whereas thiabendazole is the most toxic one on fish. Furthermore, relative toxicity of malathion (RT) equals to 1 indicating standard effects, whereas other compounds have higher RT values in D.magna test. On the other hands, RT value for malathion was not the lowest value for fish test. These data suggest that fish is more resistance to malathion than D.magna. Furthermore, visual rating of toxicity is presented in Figure 5.

\section{Conclusion}

This study demonstrated the toxicity of the tested compounds to important aquatic organisms. Malathion was the most potent chemical and has a low $\mathrm{EC}_{50}$ value $(0.43 \mathrm{mg} / \mathrm{l})$ compared to $\mathrm{EC}_{50}$ value of bromacil $(0.59 \mathrm{mg} / \mathrm{l})$. Mixture of bromacil and malathion has a larg $\mathrm{EC}_{50}$ value (0.64 TU) mixture indicating potential antagonistic effect.

Thiabendazole is more toxic to fish than malathion. RT of thiabendazole lower than malathion indicating that thiabendazole is nearly 4 times more toxic than malathion.

Furthermore, malathion showed gradual decreases in AChE activity and elevation of AST and ALT.

In conclusion malathion and bromacil have strong effect on D. magna. In general, low contamination of malathion bromacil, and thiabendazole are not safe to the aquatic organisms.

\section{Acknowledgments}

Prof Dr El-Nahhal would like to thank Alexander von Humboldt Foundation for a Research Fellowship in Berlin Germany.

Conflict of interest

We declare no conflict of interest

Funding

No funds 


\section{References}

[1] Al-Arifi SN, RM Al-Agha, ZY El-Nahhal (2013) Hydrogeology and Water Quality of Umm Alradhma Aquifer, Eastern Saudi Arabia. J. Environ.Earth Sci.3, 118-127.

[2] Al-Arifi SN, RM Al-Agha, ZY El-Nahhal (2013) Environmental Impact of Landfill on Groundwater, South East of Riyadh, Saudi Arabia. Journal of Natural Sciences Research.3,222-242.

[3] Safi J.; Abu Foul, N.; El-Nahhal Y.; El-Sebae A (2002) Monitoring of pesticide residues on cucumber, tomatoes and strawberries in Gaza Governorates, Palestine. Nahrung/Food 46 (1):34-49.

[4] El-Nahhal Y., (2004). Contamination and safety status of plant food in Arab countries. Journal of Applied Science., 4:411-417.

[5] El-Nahhal Y and Radwan A., (2013). Human Health Risks: Impact of Pesticide Application. Journal of Environment and Earth Science. 3, (7): 199-209.

[6] El-Nahhal Y.; Safi J. (2008) Removal of Pesticide Residues from Water by Organo-Bentonites. Proc. The Twelfth International Water Technology Conference pp 1711-1724. Alexandria, Egypt.

[7] El-Nahhal Y. (2006) contamination of groundwater with heavy metals in Gaza. Proc. The Tenth International Water Technology Conference. Alexandria, Egypt. pp: 1139-1150

[8] El-Nahhal Y., Lubbad R. (2018) Acute and single repeated dose effects of low concentrations of chlorpyrifos, diuron, and their combination on chicken.

Environmental Science and Pollution Research, 25(11), 10837-10847. https://doi.org/10.1007/s11356-

018-1313-y

[9] El-Nahhal Y., Harrarah S. (2013) Contamination of groundwater and associated disease: Case Study from Khan Younis Governorate, Gaza, PNA. Journal of Environment and Earth Science Vol. 3, No.5, pp 147153

[11] Abed M.A., Safi M. N., Köster J., Beer D., El-Nahhal Y, Rullkötter J, et al., (2002).Microbial Diversity of a Heavily Polluted Microbial Mat and Its Community Changes Following Degradation of Petroleum Compounds. Applied Environmental Microbiology, 68: 1674-1683.

[12] Safi, J., Awad, Y. and El-Nahhal, Y., (2014). Bioremediation of Diuron in Soil and by Cyanobacterial Mat. Am. J. Plant Sci. 5:1081-1089.

[13]Safi, J., El-Nahhal, Y., Soliman, S. A. and Elsebae A. H., (1993). Mutagenic and carcinogenic pesticides used in the Gaza Strip Agricultural Environmental. Sci.Total Environ. 132: 371-380.

[14] El-Nahhal Y and EL-dahdouh N., (2015). Toxicity of Amoxicillin and Erythromycin to Fish and Mosquito. Ecotoxicology and Environmental Contamination, 10,1:13-21.Doi: 10.5132/eec.2015.01.03.

[15] El-Nahhal Y and Hamdona N., (2015). Phytotoxicity of Alachlor, Bromacil and Diuron as Single or mixed herbicides applied to wheat, melon, and molokhia. SpringerPlus, 4:364,1-19.doi.10.1186/s40064015-1148-7.

[16] Uno, S., Shintoyo, A., (2011). Gas chromatography-mass spectrometry for metabolite profiling of Japanese medaka (Oryzias latipes) juveniles exposed to malathion.Environ Sci Pollut Res Int., 19, 7 :2595605.

[17] Waldhoff, D., Furch, B. and Junk, W.J., (2002). Fluorescence parameters, chlorophyll concentration, and anatomical features as indicatorsfor flood adaptation of an abundant tree species in centralAmazonia: Symmeria paniculata. Environ. Exp Bot., 48: 225-235.

[18] EL-Nahhal Y., Kerkez, M.F.S Abu Heen Z. (2015). Toxicity of Diuron, Diquat and Terbutryn Cyanobacterial Mats. Ecotoxicol. Environ. Contam., v. 10, n. 1, 2015, 71-82. https://dx.doi.org/10.5132/eec.2015.01.11.

[19] EL-Nahhal Y., Alshanti A. (2015) Toxicity of Single and Mixtures Antibiotics to Cyanobacteria. Environment and analytical Toxicology,5,3:1-8.dx.doi.org/10.4172/2161-0525.1000274.

[20] Lal ,B., Sarang, M.K. and Kumar,P., (2013). Malathion exposure induces the endocrine disruption and growth retardation in the catfish, Clarias batrachus (Linn.).Gen Comp Endocrino. 181:139-145.

[21] Alavi, G1., Sanda, M., Loo, B., Green, RE. and Ray, C.,( 2008).Movement of bromacil in a Hawaii soil under pineapple cultivation - a field study.doi: 10.1016/j.chemosphere. 72(1):45-52. 
[22] Yonar, S.M., (2013). Toxic effects of malathion in carp, Cyprinus carpio carpio: Protective role of lycopene. Ecotoxicol Environ Saf., 97:223-229.

[23] Patil, VK. and David, M., (2013). Oxidative stress in freshwater fish, Labeo rohita as a biomarker of malathion exposure. Environ Monit Assess.

[24] Tomlin, C. The Pesticide Manual. British Crop Protection Council, UK.2000.

[25] El-Nahhal Y. (2018) Toxicity of some aquatic pollutants to fish. Environ Monit Assess. 2018 Jul 4;190(8):449. doi: 10.1007/s10661-018-6830-0.

[26] Yasser EN., EL-Najjar Sh and Afifi, S., (2015) Toxicity of Carbaryl, Chlorpyrifos and Diuron to Different Aquatic Organisms. Toxicology International . 22,(1): 1-9.

[27] Ellman G L, Courtney K D, Andres V Jr, Feather-Stont R M. A new and rapid colorimetinc determination of acetylcholinesterase activity. Biochemistry and Pharmacology. 1961;7: 88-95.

[28] Reitman S, Frankel S A. Colorimetric method for determination of serum glutamate oxaloacetic acid and pyruvic acid transaminases. American Journal of Clinical Pathology. 1957; 29: 56-63.

[29] Kid, P.R.N.; King, E.G., 1954. Colorimetric determination of alkaline phosphatase activity. J. Clin. Path. $6,322$.

[30] Al-Kurdi, S., Al-Louh, M.O., Al-Agha, M.R. and El-Nahhal,Y. (2018) Development of Analytical Method for the Detection of Nemacur Residues in Cucumber Fruits. American Journal of Analytical Chemistry, 9, 6476. https://doi.org/10.4236/ajac.2018.91006.

[31] Alloh, M.O., AL-Kurdi, S., Alagha, M.R. and Yasser, E.-N. (2018) Nemacur Residue Analysis in Soil Water and Cucumber Samples Collected from the Field in Gaza Strip, Palestine. American Journal of Plant Sciences, 9, 517-530. https://doi.org/10.4236/ajps.2018.93039

[32] El-Nahhal Y, Nir S, Polubesova T, Margulies L and Rubin B., (1998). Leaching, phytotoxicity and weed control of new formulations of alachlor. Journal of Agricultural. Food Chemistry. 46:3305-3313.

[33] Malhat F, Nasr I, 2011. Organophosphorus Pesticides Residues in Fish Samples from the River Nile Tributaries in Egypt. Bull Environ Contamination and Toxicology. 87:689-692. DOI 10.1007/s00128-0110419-4

[34] El-Nahhal Y., EL-dahdouh N., Hamdona N., Alshanti A. (2016). Toxicological Data of Some Antibiotics and Pesticides to Fish, Mosquitoes, Cyanobacterial Mats and to Plants. Data In Brief: 6, 871-880. .https://dx.doi.org/10.1016/i.dib.2016.01.051

[35] Dos Santos, AA., Naime, AA., de Oliveira, J., Colle, D., Dos Santos ,DB., Hort MA.,et al., (2015). Longterm and low-dose malathion exposure causes cognitive impairment in adult mice: evidence of hippocampal mitochondrial dysfunction, astrogliosis and apoptotic events. Arch Toxicol. 